\title{
MOBILISASI DINI IBU POST SECTIO CAESAREA DI RSUD SOREANG
}

\author{
Wati Fitri Rachma, Kamsatun \\ Poltekkes Kemenkes Bandung \\ email: Kamsatun70@gmail.com
}

\begin{abstract}
AKI in Indonesia in 2012 is still high at 359 deaths per 100,000 live births. The cause of maternal death is bleeding, infection, eclampsi and others. Infection is a complication that occurs in many post-sectio caesarea patients due to surgical wounds. This complication can be prevented by performing physical monitoring and early mobilization actions. The benefit of early mobilization is to accelerate wound healing, with mobilization to facilitate the circulation of blood. This research is to know the implementation of early mobilization on post-sectio caesarea patients in RSUD Soreang Kabupaten Bandung 2018. The type of descriptive research is quantitative, the population is the mother who gave birth with a sectio caesarea in RSUD Soreang. Sampling with accidental sampling obtained 31 respondents. The results showed that of 31 post-sectio caesarea mothers as much as 3 people (9.7\%) carried out early mobilization so categorized well. While as many as 28 people (90.3\%) did not conduct early mobilization well so categorized not good. It is suggested to health workers to be more intensive in giving motivation and motivation to post SC mothers in early mobilization.
\end{abstract}

Keywords : implementation, early mobilization, sectio caesaea

\begin{abstract}
ABSTRAK
AKI di Indonesia tahun 2012 masih tinggi sebesar 359 kematian per 100.000 kelahiran hidup. Penyebab kematian ibu yaitu perdarahan, infeksi, eklampsi dan lain-lain. Infeksi merupakan komplikasi yang banyak terjadi pada ibu post sectio caesarea akibat luka operasi. Komplikasi ini dapat dicegah dengan melakukan pemantauan fisik dan tindakan mobilisasi dini. Manfaat dari mobilisasi dini adalah mempercepat penyembuhan luka, dengan mobilisasi dapat memperlancar peredaran darah. Penelitian ini untuk mengetahui gambaran pelaksanaan mobilisasi dini pada ibu postsectio caesarea di RSUD Soreang Kabupaten Bandung 2018. Jenis penelitian deskriptif kuantitatif, populasi adalah ibu yang melahirkan dengan sectio caesarea di RSUD Soreang. Pengambilan sampel dengan accidental sampling diperoleh 31 responden. Hasil penelitian menunjukan bahwa dari 31 ibu postsectio caesarea sebanyak 3 orang (9,7\%) melaksanakan mobilisasi dini sehingga dikategorikan baik. Sedangkan sebanyak 28 orang (90,3\%) tidak melaksanakan mobilisasi dini dengan baik sehingga dikategorikan tidak baik. Disarankan kepada tenaga kesehatan untuk lebih intensif dalam memberikan semangat dan motivasi pada ibu post SC dalam melakukan mobilisasi dini.
\end{abstract}

Kata kunci : pelaksanaan, mobilisasi dini, sectio caesarea 


\section{PENDAHULUAN}

Angka kematian ibu (AKI) adalah jumlah kematian ibu yang disebabkan oleh kehamilan, persalinan, dan nifas atau pengelolaannya tetapi bukan disebabkan karena penyebab lain seperti kecelakaan atau terjatuh, di setiap 100.000 kelahiran hidup (Kementerian Kesehatan RI, 2016). Berdasarkan Survei Demografi dan Kesehatan Indonesia (SDKI) tahun 2012, angka kematian ibu di Indonesia masih tinggi yaitu sebesar 359 per 100.000 kelahiran hidup. Profil Kesehatan Provinsi Jawa Barat berdasarkan survey yang dilaksanakan Badan Pusat Statistik Provinsi Jawa Barat tahun 2014 menunjukan bahwa AKI Provinsi Jawa Barat sebesar 321,15 per 100.000 kelahiran hidup. Jawa Barat menjadi penyumbang $50 \%$ jumlah kematian ibu di Indonesia. Penyebab kematian ibu berdasarkan Profil Kesehatan Provinsi Jawa Barat tahun 2014 yaitu perdarahan $(58,79 \%)$, infeksi $(9,62 \%)$, eklampsi $(13,60 \%)$, lain-lainnya (17,99\%). Pada umumnya kematian ibu terjadi pada saat melahirkan $(60,87 \%)$, waktu nifas $(30,43 \%)$ dan waktu hamil $(8,70 \%)$. Infeksi merupakan komplikasi yang banyak terjadi pada ibu post sectio caesarea. Hasil Riskesdas tahun 2013 menunjukkan bahwa kelahiran dengan bedah caesarea di Indonesia yaitu sebesar
9,8\% dengan proporsi tertinggi yaitu di DKI Jakarta $(19,9 \%)$, sementara kelahiran dengan bedah caesarea di Provinsi Jawa Barat yaitu sebesar 7,5\%. Sebanyak $19,50-27,30 \%$ diantaranya merupakan sectio caesarea karena CPD (Cephalo Pelvik Disproporsi), perdarahan hebat 11,90- $21 \%$, karena kelainan letak 4,30$8,70 \%$ (Kasdu, 2003). Survei Demografi dan Kesehatan Indonesia (SDKI) tahun 2012 menyatakan ibu yang melahirkan melalui bedah caesarea banyak mengalami komplikasi dibandingkan dengan wanita lainnya. Depkes, 2006 dalam penelitian Hartati (2014) mengatakan bahwa infeksi merupakan komplikasi yang banyak terjadi pada ibu pasca sectio caesarea akibat luka operasi dengan angka kejadian 25 kali lebih tinggi dibandingkan kejadian infeksi pada persalinan pervaginam yang menunjukkan angka 40-80 per 100.000 kelahiran dengan tindakan operasi sectio caesarea. Komplikasi post operasi caesarea, dapat menyebabkan ruptur pada dinding uteri atau masalah hoemostasis pada sirkulasi darah sehingga terjadi perdarahan dan infeksi dengan jumlah $46 \%$ dari seluruh ibu yang dirawat. Komplikasi ini dapat dicegah dengan melakukan pemantauan fisik dan tindakan mobilisasi dini pada ibu pasca operasi 
sectio caesarea (Jokhan dan Holmeyr, 2009).

Mobilisasi dini merupakan suatu aspek yang terpenting pada fungsi fisiologis karena hal itu esensial untuk mempertahankan kemandirian (Carpenito, 2000). Salah satu keuntungan dari mobilisasi dini adalah mempercepat penyembuhan luka, dengan mobilisasi dapat memperlancar peredaran darah (Kasdu, 2003). Penelitian yang dilakukan oleh Barid (2011), menunjukan bahwa mobilisasi dini pada ibu post sectio caesarea mempercepat proses penyembuhan luka dan mengurangi hari rawat inap dengan rata-rata lama hari rawat inap pada kelompok perlakuan yaitu 3,15 sedangkan pada kelompok kontrol yaitu 3,6. Salah satu tempat pelayanan kesehatan yang ada di Jawa Barat adalah Rumah Sakit Umum Daerah Soreang. Rumah sakit ini terletak di pusat ibu kota Kabupaten Bandung yaitu di Soreang. Berdasarkan hasil studi pendahuluan yang dilaksanakan di RSUD Soreang Kabupaten Bandung pada Sabtu, 3 Maret 2018, didapatkan angka kejadian ibu yang melahirkan dengan operasi sectio caesarea lebih tinggi dari angka kejadian ibu yang melahirkan dengan spontan. Rata-rata kejadian sectio caesarea di RSUD soreang dalam 3 bulan terakhir (November 2017, Desember 2017, dan Januari 2018) yaitu
79 orang. Indikasi terbanyak yaitu CPD (Cephalo Pelvik Disproporsi), letak sungsang, serta pernah dilakukkan sectio caesarea. Dalam 3 bulan terakhir, terdapat 3 pasien post sectio caesarea dirawat ulang akibat infeksi luka post sectio caesarea. Hasil wawancara kepada 8 ibu post sectio caesarea yang dirawat di ruang nifas RSUD Soreang Kabupaten Bandung pada tanggal 17 Maret 2018, semua ibu post sectio caesarea melakukan latihan pernapasan sedini mungkin, 5 ibu post sectio caesarea menggerakkan tangan dan kaki pada 6 jam pertama, 4 ibu post sectio caesarea miring kanan dan kiri setelah 6 jam operasi dengan bimbingan perawat yang bertugas, 4 ibu post sectio caesarea belajar duduk pada jam ke- 8-12 setelah operasi dengan bimbingan perawat yang bertugas, dan 4 ibu post sectio caesarea berjalan pada 24 jam setelah operasi dengan bimbingan perawat yang bertugas. Tujuan penelitian ini yaitu untuk mengetahui bagaimana gambaran pelaksanaan mobilisasi dini pada ibu post sectio caesarea di RSUD Soreang Kabupaten Bandung 2018.

\section{METODE}

Penelitian ini dilakukan dengan metode deskriptif pendekatan kuantitatif. Teknik pengambilan sampel berjumlah 31 responden dengan menggunakan 
accidental samplingyaitu pasien-pasien sectio caesarea yang dirawat pada saat pengambilan data bulan Maret 2018. Pengambilan data dilakukan di ruang nifas RSUD Soreang Kabupaten Bandung. Instrumen yang digunakan dengan menggunakan lembar wawancara dan data responden yang didapatkan dari status pasien. Instrumen ini termasuk kategorik reliabel karena memiliki nilai lebih dari 0,7. Cara pengumpulan data dengan teknik wawancara dan studi dokumentasi. Analisis data yang digunakan yaitu Analisa univariat.

\section{HASIL DAN PEMBAHASAN}

Dalam penelitian ini, diketahui bahwa berdasarkan usia, terdapat 22 responden (71\%) yang tidak memiliki risiko kehamilan dimana dari 22 responden tersebut 3 responden $(13,6 \%)$ melakukan mobilisasi dini dengan baik. Sedangkan pada kategori berisiko terdapat 9 responden dan seluruhnya tidak melakukan mobilisasi dini dengan baik. Hal ini menunjukkan pada usia berisiko justru tidak ada seorangpun responden yang melaksanakan mobilisasi dini dengan baik, berbeda dengan pada usia tidak berisiko, terdapat 3 responden $(13,6 \%)$ yang melaksanakan mobilisasi dini dengan baik. Selain itu berdasarkan karakteristik pendidikan responden, diketahui bahwa pada tingkat pendidikan SD, keseluruhan responden yaitu 6 orang tidak melakukan mobilisasi dini dengan baik. Pada responden dengan tingkat pendidikan SLTP diketahui bahwa sebanyak 2 responden $(20 \%)$ melakukan mobilisasi dini dengan baik, sedangkan 8 lainnya tidak melakukan mobilisasi dini dengan baik. Karakteristik responden dalam penelitian ini dapat dilihat pada table 1 .

Tabel 1 menunjukan Terdapat 9 (29\%) ibu yang usianya beresiko yaitu kisaran kurang dari 20 tahun dan lebih dari 35 tahun. Sebagian besar responden sebanyak 22 (71\%) tidak beresiko. Mayoritas responden berpendidikan SLTA dengan jumlah 12 orang (38,7\%). Mayoritas responden tidak bekerja atau sebagai Ibu Rumah Tangga dengan jumlah sebanyak 25 orang $(80,6 \%)$. Responden dengan multipara lebih dari setengah, berjumlah sebanyak 19 orang (61\%). Mayoritas responden melakukan sectio caesarea karena riwayat SC atau pernah dilakukan sectio caesarea sebelumnya sebanyak 10 orang $(32,2 \%)$ dan Cephalo Pelvic Disproportion (CPD) sebanyak 8 orang $(25,8 \%)$. Skala nyeri yang paling banyak dialami oleh responden adalah skala nyeri sedang dengan total sebanyak 17 orang $(54,8 \%)$. Dari 31 responden yang dilakukan sectiocaesarea, mayoritas responden sebanyak 21 orang $(67,7 \%)$ belum pernah 
dilakukan sectiocaesarea. Seluruhan yang normal dengan total sebesar $100 \%$. responden mempunyai tanda-tanda vital

Tabel 1. Karakteristik Ibu Post Sectio Caesarea di RSUD Soreang Kabupaten Bandung Tahun 2018

\begin{tabular}{|c|c|c|c|}
\hline No. & Karakteristik & Frekuensi (F) & Persentase (\%) \\
\hline \multirow[t]{4}{*}{1} & Umur & & \\
\hline & Tidak Beresiko & 22 & 71 \\
\hline & Beresiko & 9 & 29 \\
\hline & Total & 31 & 100 \\
\hline \multirow[t]{7}{*}{2} & Pendidikan & & \\
\hline & SD & 6 & 19,4 \\
\hline & SLTP & 10 & 32,3 \\
\hline & SLTA & 12 & 38,7 \\
\hline & Diploma & 2 & 6,5 \\
\hline & S1 & 1 & 3,2 \\
\hline & Total & 31 & 100 \\
\hline \multirow[t]{4}{*}{3} & Pekerjaan & & \\
\hline & Pegawai Swasta & 6 & 19,4 \\
\hline & IRT & 25 & 80,6 \\
\hline & Total & 31 & 100 \\
\hline \multirow[t]{4}{*}{4} & Paritas & & \\
\hline & Primpara & 12 & 39 \\
\hline & Multipara & 19 & 61 \\
\hline & Total & 31 & 100 \\
\hline \multirow[t]{10}{*}{5} & Indikasi Sectio & & \\
\hline & Caeserea & & \\
\hline & Riwayat SC & 10 & 32,3 \\
\hline & $\mathrm{CPD}$ & 8 & 25,8 \\
\hline & Letak Sungsang & 5 & 16,1 \\
\hline & KPD & 4 & 12,9 \\
\hline & PEB & 2 & 6,5 \\
\hline & Gemelli & 1 & 3,2 \\
\hline & Solutio Placenta & 1 & 3,2 \\
\hline & Total & 31 & 100 \\
\hline \multirow[t]{5}{*}{6} & Skala Nyeri & & \\
\hline & Nyeri Ringan & 4 & 12,9 \\
\hline & Nyeri Sedang & 17 & 54,8 \\
\hline & Nyeri Berat & 10 & 32,3 \\
\hline & Total & 31 & 100 \\
\hline \multirow[t]{5}{*}{7} & Riwayat Sectio & & \\
\hline & Caeserea & & \\
\hline & Tidak Pernah & 21 & 67,7 \\
\hline & Pernah & 10 & 32,3 \\
\hline & Total & 31 & 100 \\
\hline \multirow[t]{3}{*}{8} & Tanda-tanda Vital & & \\
\hline & Normal & 31 & 100 \\
\hline & Total & 31 & 100 \\
\hline
\end{tabular}


Guna mengetahui kategori pelaksanaan mobilisasi dini di RSUD Soreang
Kabupaten Bandung dapat dilihat pada table 2 dibawah ini:

Tabel 2. Distribusi Frekuensi Pelaksanaan Mobilisasi Dini pada Ibu Post Sectio Caesarea di Rumah Sakit Umum Daerah Soreang Kabupaten Bandung tahun 2018

\begin{tabular}{clcc}
\hline No & Hasil & Frekuensi & $\begin{array}{c}\text { Presentase } \\
(\boldsymbol{\%})\end{array}$ \\
\hline 1 & Baik & 3 & $9,7 \%$ \\
\hline 2 & Tidak Baik & 28 & $90,3 \%$ \\
\hline & Total & 31 & $100 \%$ \\
\hline
\end{tabular}

Berdasarkan tabel, didapatkan bahwa sebagian kecil responden yang melaksanakan mobilisasi dini sehingga mendapatkan kategori baik berjumlah 3 orang $(9,7 \%)$. Sedangkan sebagian besar responden tidak melaksanakan mobilisasi dini dengan baik sehingga dikategorikan tidak baik dengan jumlah 28 orang $(90,3 \%)$.

Pada tingkat pendidikan SLTA sebanyak 1 responden $(8,3 \%)$ melakukan mobilisasi dini dengan baik sedangkan 11 responden lainnya tidak melakukan mobilisasi dini dengan baik. Pada tingkat pendidikan Diploma diketahui keseluruhan responden yaitu 2 orang tidak melakukan mobilisasi dini dengan baik. Pada tingkat pendidikan S1 diketahui keseluruhan responden yaitu 1 orang tidak melakukan mobilisasi dini dengan baik. Berdasarkan karakteristik pekerjaan diketahui bahwa hanya terdapat
2 jenis pekerjaan responden yaitu pegawai swasta dan Ibu Rumah Tangga (IRT).

Pada pekerjaan pegawai swasta terdapat 1 responden $(16,7 \%)$ yang melaksanakan mobilisasi dini dengan baik sedangkan 5 lainnya tidak melaksanakan mobilisasi dini dengan baik. Pada IRT, terdapat 2 responden $(8 \%)$ melaksanakan mobilisasi dini dengan baik, sedangkan 23 lainnya tidak melaksanakan mobilisasi dini dengan baik. Selain, itu berdasarkan skala nyeri dapat diketahui bahwa pada kategori nyeri berat terdapat 1 responden $(10 \%)$ yang melaksanakan mobilisasi dini dengan baik sedangkan 9 responden lainnya tidak melaksanaan mobilisasi dini dengan baik.

Untuk mengetahui hubungan antara umur, pendidikan, pekerjaan, paritas, skala nyeri, dan riwayat sectio caesarea dengan pelaksanaan mobilisasi dini dapat dilihat pada table 3 . 
Tabel 3. Distribusi Frekuensi Pelaksanaan Mobilisasi Dini pada Ibu Post Sectio Caesarea Berdasarkan Karakteristikdi Rumah Sakit Umum Daerah Soreang Kabupaten Bandung tahun 2018

\begin{tabular}{|c|c|c|c|c|c|c|}
\hline \multirow[b]{2}{*}{$\begin{array}{l}\text { Mobilisasi Dini } \\
\text { Karakteristik }\end{array}$} & \multicolumn{2}{|c|}{ Baik } & \multicolumn{2}{|c|}{ Tidak Baik } & \multicolumn{2}{|c|}{ Total } \\
\hline & $\mathbf{n}$ & $\%$ & $\mathbf{n}$ & $\%$ & $\mathbf{n}$ & $\%$ \\
\hline \multicolumn{7}{|l|}{ Usia } \\
\hline - Beresiko & 0 & 0 & 9 & 100 & 9 & 100 \\
\hline - Tidak Beresiko & 3 & 13,6 & 19 & 90,4 & 21 & 100 \\
\hline \multicolumn{7}{|l|}{ Pendidikan } \\
\hline - SD & 0 & 0 & 6 & 100 & 6 & 100 \\
\hline - SLTP & 2 & 20 & 8 & 80 & 10 & 100 \\
\hline - SLTA & 1 & 8,3 & 11 & 91,7 & 12 & 100 \\
\hline - Diploma & 0 & 0 & 2 & 100 & 2 & 100 \\
\hline$-\mathrm{S} 1$ & 0 & 0 & 1 & 100 & 1 & 100 \\
\hline \multicolumn{7}{|l|}{ Pekerjaan } \\
\hline \multirow{2}{*}{$\begin{array}{l}\text { - Pegawai Swasta } \\
\text { - IRT }\end{array}$} & 1 & 16,7 & 5 & 83,3 & 6 & 100 \\
\hline & 2 & 8 & 23 & 92 & 25 & 100 \\
\hline \multicolumn{7}{|l|}{ Paritas } \\
\hline - Primipara & 1 & 8 & 11 & 92 & 12 & 100 \\
\hline - Multipara & 2 & 10,5 & 17 & 89,5 & 19 & 100 \\
\hline \multicolumn{7}{|l|}{ Skala Nyeri } \\
\hline - Nyeri Ringan & 0 & 0 & 4 & 100 & 4 & 100 \\
\hline \multicolumn{7}{|l|}{ - Nyeri Sedang } \\
\hline \multirow[t]{2}{*}{ - Nyeri Berat } & 2 & 11,8 & 15 & 88,2 & 17 & 100 \\
\hline & 1 & 10 & 9 & 90 & 10 & 100 \\
\hline \multicolumn{7}{|l|}{ Riwayat SC } \\
\hline - Pernah & 1 & 10 & 9 & 90 & 10 & 100 \\
\hline - Tidak Pernah & 2 & 9,5 & 19 & 90,5 & 21 & 100 \\
\hline
\end{tabular}

Pada kategori nyeri skala sedang, terdapat 2 responden $(11,8 \%)$ yang melaksanakan mobilisasi dini dengan baik, sedangkan 15 orang lainnya tidak melaksanakan mobilisasi dini dengan baik. Pada kategori nyeri skala ringan keseluruhan responden yaitu 4 orang tidak melaksanakan mobilisasi dini dengan baik. Dari kategori paritas, pada multipara terdapat 2 responden $(10,5 \%)$ yang melaksanakan mobilisasi dini dengan baik, sedangkan 17 lainnya tidak melaksanakan mobilisasi dini dengan baik. Pada responden primpara, terdapat 1 responden $(8 \%)$ yang melaksanakan mobilisasi dini dengan baik sedangkan 11 responden lainnya tidak melaksanakan mobilisasi dini dengan baik. Berdasarkan karakteristik riwayat SC, pelaksanaan mobilisasi dini dengan kategori baik secara frekuensi lebih banyak terjadi pada responden dengan riwayat SC yaitu sebesar 10\%, sedangkan pada responden yang tidak pernah mengalami riwayat SC sebesar $9,5 \%$. 
Dalam penelitian ini karkteristik usia yang tidak mengalami resiko atau usia berkisar antara 20-35 tahun lebih banyak jumlahnya dibandingkan dengan usia yang beresiko. Usia dibawah 20 tahun dan diatas 35 tahun akan meningkatkan resiko kehamilan dan persalinan. Dari segi psikologis, pada wanita kurang dari 20 tahun perkembangan kejiwaannya masih belum matang untuk menjadi seorang ibu. Usia lebih dari 35 tahun termasuk kedalam golongan usia beresiko tinggi dalam kehamilan dan persalinan (Solehati, 2015). Terlihat dari usia ibu post sectio caesarea di atas mayoritas terdapat pada usia yang aman untuk kehamilan dan persalinan. Hal tersebut berkaitan dengan tingkat kesadaran responden yang tinggi dalam menjaga kesehatan yang didukung dengan usia responden saat hamil berada di usia yang ideal. Dalam penelitian ini tingkat pendidikan ibu yang mengalami caesarea adalah pendidikan menengah dengan jumlah terbanyak adalah SLTA sebanyak 12 orang $(38,7 \%)$ dan SLTP sebanyak 10 orang $(32,3 \%)$. Pendidikan mempunyai peran yang sangat penting, responden yang berpendidikan tinggi pada umumnya telah terpapar dengan hal-hal yang berkaitan dengan perawatan paska persalinan, termasuk dengan cara operasi, diasumsikan bahwa mereka telah banyak mendapatkan informasi dari berbagai media (Winarsih, 2013). Ibu post sectio caesarea yang tidak bekerja atau sebagai Ibu Rumah Tangga lebih banyak jumlahnya dibandingkan dengan ibu yang bekerja sebagai karyawan swasta. Pekerjaan merupakan salah satu penyebab dilakukannya tindakan caesar dalam proses persalinan, ibu yang memiliki pekerjaan berat selama kehamilan, besar kemungkinan akan mengalami komplikasi pada kehamilannya. Hasil penelitian ini sejalan dengan penelitian yang dilakukan oleh Risna (2013) dengan judul hubungan umur dan pekerjaan ibu hamil dengan rencana proses persalinan caesarea di RSUD Hasan Sadikin Bandung Jawa Barat Tahun 2013. Hasil penelitian yang didapatkan adalah responden yang melakukan persalinan dengan tindakan SC adalah responden yang tidak bekerja dengan jumlah responden sebanyak 89 responden (31\%). Responden yang tidak bekerja adalah responden yang memiliki aktivitas sebagai ibu rumah tangga, pekerjaan mengurus rumah, anak dan suami dapat menyebabkan ibu bekerja terlalu berat apabila tidak memiliki seseorang yang membantu ibu dalam masa kehamilan sehingga kemungkinan dapat terjadi masalah pada kehamilannya yang menyebabkan ibu harus dilakukan tindakan pada persalinan dengan tindakan caesarea. Hartatik (2013) menyatakan 
bahwa faktor yang mempengaruhi persalinan sectio caesarea pada ibu yang tidak bekerja antara lain bayi besar, panggul sempit, foetal dystres, placenta previa, ketuban pecah dini, kelainan letak pada janin, faktor power dari ibu. Pekerjaan dalam hal ini juga dapat mempengaruhi ibu bersalin dalam melakukan perawatan selama masa bersalin pada ibu post SC, dimana ibu yang bekerja akan mudah mendapatkan informasi dibandingkan dengan ibu yang tidak bekerja. Pada ibu yang tidak bekerja, kemungkinan besar memiliki waktu yang cukup banyak untuk mencari informasi dan mendatangi faslitas kesehatan untuk melakukan konsultasi mengenai perawatan diri selama masa bersalin SC. Sedangkan pada ibu yang bekerja kemungkinan tidak memiliki waktu luang yang cukup untuk mencari infromasi yang disebabkan karena terbatasnya waktu akibat jam kerja yang padat. Selain itu, pengaruh pekerjaan terhadap perawatan dan penyembuhan luka pada masa bersalin terutama pada ibu bersalin sectio caesarea yaitu pada ibu yang tidak bekrja biasanya pola istirahat lebih teratur, pikiran ibu lebih tenang sehingga proses penyembuhan luka lebih cepat dibandingkan dengan ibu yang bekerja (Suciati, 2015).Mayoritas ibu yang melahirkan adalah multipara. Notoatmojo (2003) mengemukakan bahwa ibu yang sudah pernah mengalami kehamilan dan persalinan, minimal mereka sudah terpapar banyak informasi tentang masalah kehamilan dan persalinan. Maka seharusnya pelaksanaan mobilisasi dini ibu post sectio caesarea sudah berada pada kategori baik. Maka diharapkan dengan banyaknya ibu post sectio caesarea yang berada pada paritas multipara ini mereka sudah sering terpapar informasi yang membuat pengetahuan mereka baik, yang didukung juga dengan pengalaman hamil dan melahirkan sebelumnya yang dapat mempegaruhi pelaksanaan mobilisasi dini pada ibu post sectio caesarea menjadi lebih baik. Indikasi sectio caesarea terbanyak yang dialami oleh ibu mayoritas dikarenakan riwayat SC sebelumnya. Hasil ini sesuai dengan penelitian Suciati (2015) yang menyatakan bahwa mayoritas ibu bersalin sectio caesarea memiliki riwayat persalinan SC sebelumnya yaitu sebanyak $(72,1 \%)$. Hal ini membuktikan bahwa riwayat persalinan sebelumnya mempengaruhi pada persalinan berikutnya, ibu yang memiliki riwayat persalinan sectio caesarea kemungkinan besar akan melakukan proses persalinan berikutnya dengan menggunakan jenis persalinan yang sama yaitu dengan tindakan operasi caesarea. Hal ini disebabkan karena sebagian besar responden pada persalinan sebelumnya dilakukan tindakan persalinan 
dengan SC sehingga pada saat persalinan selanjutnya kemungkinan besar ibu juga bersalin secara SC. Sesuai dengan pendapat Ambarwati (2008) yang menyatakan bahwa seorang ibu yang melakukan persalinan dengan SC, maka pada persalinan selanjutnya juga akan dilakukan persalinan dengan SC. Skala nyeri yang dialami ibu mayoritas merasakan nyeri sedang. Hasil penelitian ini sesuai dengan hasil penelitian Solehati (2015) yang menyatakan bahwa pasien sectio caesarea mengalami nyeri sedang sampai berat sebanyak 93\%.Intensitas nyeri merupakan respon klien terhadap nyeri yang diukur dengan menggunakan skala nyeri dan hal ini sangat individual tergantung pada bagaimana seseorang mempersepsikan nyeri (Winarsih, 2013). Nyeri dapat mempengaruhi kualitas hidup antara lain gangguan mobilisasi, gangguan tidur dan dapat menimbulkan dampak yang lebih hebat yaitu klien menjadi tidak sadar, nyeri merupakan masalah utama yang dirasakan oleh sebagian besar pasien yang mengalami hospitalisasi, termasuk didalamnya pasien paska operasi (Winarsih, 2013). Hasil tanda-tanda vital yang telah tercantum dalam rekam medik responden, didapatkan hasil bahwa tekanan darah, nadi, suhu dan respirasi ibu yang diamati masih dalam batas normal. Menurut teori dalam buku Ambarwati
(2008), tekanan darah normal manusia adalah sistolik antara 90-120 $\mathrm{mmHg}$ dan diastolik 60-80 mmHg. Pasca melahirkan pada kasus normal, tekanan darah tidak berubah. Perubahan tekanan darah menjadi lebih rendah diakibatkan oleh perdarahan. Sedangkan tekanan darah tinggi pada post partum merupakan tanda terjadinya pre eklamsia post partum. Selain itu, denyut nadi normal pada orang dewasa 6080 kali per menit. Pasca melahirkan, denyut nadi dapat menjadi bradikardi maupun lebih cepat. Denyut nadi yang melebihi 100 kali per menit, harus waspada kemungkinan infeksi atau perdarahan post partum.Frekuensi pernafasan normal pada orang dewasa adalah 16-24 kali per menit. Pada ibu post partum umumnya pernafasan lambat atau normal. Hal ini dikarenakan ibu dalam keadaan pemulihan atau dalam kondisi istirahat. Suhu tubuh wanita inpartu tidak lebih dari $37,2^{\circ} \mathrm{C}$. Pasca melahirkan, suhu tubuh dapat naik kurang lebih $0,5^{\circ} \mathrm{C}$ dari keadaan normal. Kenaikan suhu akibat kehilangan cairan dan kelelahan kerja keras pada saat proses persalinan,. Kurang lebih pada hari ke-4 post partum, suhu badan akan naik lagi.

Berdasarkan hasil penelitian ini, didapatkan bahwa sebagian kecil responden yang melaksanakan mobilisasi 
dini sehingga mendapatkan kategori baik berjumlah 3 orang $(9,7 \%)$. Sedangkan sebagian besar responden tidak melaksanakan mobilisasi dini dengan baik sehingga dikategorikan tidak baik dengan jumlah 28 orang $(90,3 \%)$.

Faktor-faktor yang mempengaruhi pelaksanaan mobilisasi dini pada ibu post sectio caesarea menurut Hartati (2014) yaitu usia, paritas, tingkat pendidikan, pekerjaan, serta skala nyeri selain itu pengalaman SC, pengetahuan, motivasi, dan pemberian informasi juga mempengaruhi pelaksanaan mobilisasi dini pada ibu post sectio caesarea (Winarsih, 2013). Dalam penelitian ini, usia tidak beresiko lebih banyak melaksanakan mobilisasi dini dengan baik. Hasil penelitian ini sejalan dengan penelitian Hartati (2014) bahwa usia 20-35 tahun (usia tidak beresiko) lebih banyak yang melaksanakan mobilisasi dini dibandingkan dengan usia ibu yang beresiko. Hal ini dikarenakan usia yang cukup memiliki pengetahuan, motivasi, sikap yang baik untuk melakukan mobilisasi dini (Hartati, 2014).Selain itu berdasarkan karakteristik pendidikan responden, menunjukkan bahwa baik atau tidaknya pelaksanaan mobilisasi dini tidak terkait dengan karakteristik pendidikan. Hal tersebut tergambar dari data dimana pada tingkat pendidikan dasar tidak ada responden yang melakukan mobilisasi dini dengan baik, pada tingkat pendidikan menengah pertama memang mendapat kenaikan menjadi 2 responden $(20 \%)$ yang melakukan mobilisasi dini yang baik, namun pada sekolah menengah atas jumlah tersebut mengalami penurunan menjadi 1 orang $(8,3 \%)$, bahkan pada pendidikan tinggi tidak ada satupun yang melaksanakan mobilisasi dini dengan baik. Hasil ini tidak sesuai dengan penelitian yang dilakukan oleh Hartati (2014) yang menyatakan bahwa Pendidikan mempengaruhi pelaksanaan mobilisasi dini pada ibu post sectio caesarea. Tetapi penelitian ini sejalan dengan penelitian Grace dan Nasution (2013) dimana mayoritas responden dengan tingkat pendidikan menengah sebagian melaksanakan mobilisasi dini dengan baik sedangkan sebagian lagi tidak. Setinggi apapun tidak pendidikan, namun jika seorang ibu tidak mempunyai pengetahuan sebelumnya, maka mobilisasi dini tersebut tidak akan dapat dilaksanakan dengan baik, seperti kesimpulan dari Buhari, Hutagaol, dan Kundre (2015) yang menyebutkan pengetahuan terhadap mobilisasi dini berpengaruh signifikan terhadap pelaksanaan mobilisasi dini dengan baik.Berdasarkan karakteristik pekerjaan, secara proporsi maka jumlah responden yang bekerja lebih dapat 
melaksanakan mobilisasi dini dengan baik dibandingkan dengan responden yang tidak bekerja. Hal ini dikarenakan seseorang yang bekerja pengetahuannya akan lebih luas dibandingkan dengan responden yang tidak bekerja, seperti penelitian yang dilakukan oleh Buhari, Hutagaol, dan Kundre (2015).Selain, itu berdasarkan skala nyeri dapat diketahui bahwa pada kategori nyeri sedang lebih banyak yang melaksanakan mobilisasi dini dengan baik. Hasil penelitian ini sejalan dengan penelitian Hartati (2014), bahwa ibu post SC yang mengalami nyeri sedang lebih banyak melakukan mobilisasi dini dibandingkan nyeri berat dan ringan, hal ini terjadi karena masih adanya efek anestesi pada ibu pasca operasi setelah 24 jam pertama juga pengetahuan yang dimiliki ibu cukup baik. Intensitas nyeri merupakan respon klien terhadap nyeri yang diukur dengan menggunakan skala nyeri dan hal ini sangat individual tergantung pada bagaimana seseorang mempersepsikan nyeri (Winarsih, 2013). Nyeri dapat mempengaruhi kualitas hidup antara lain gangguan mobilisasi, gangguan tidur dan dapat menimbulkan dampak yang lebih hebat yaitu klien menjadi tidak sadar, nyeri merupakan masalah utama yang dirasakan oleh sebagian besar pasien yang mengalami hospitalisasi, termasuk didalamnya pasien paska operasi
(Winarsih, 2013). Perry dan Potter (2010) mengungkapkan bahwa faktor yang mempengaruhi mobilisasi adalah faktor fisiologis yaitu salah satunya nyeri.Dari kategori paritas, pada multipara lebih banyak yang melaksanakan mobilisasi dini dengan baik. Hasil penelitian ini sejalan dengan penelitian Hartati (2014) bahwa ibu dengan multipara lebih banyak melakukan mobilisasi dini dibandingkan dengan ibu primipara. Mayoritas ibu yang melahirkan adalah multipara yang artinya mereka telah melahirkan seorang anak lebih dari satu kali (Prawirohardjo, 2012). Notoatmojo (2003) mengemukakan bahwa ibu yang sudah pernah mengalami kehamilan dan persalinan, minimal mereka sudah terpapar banyak informasi tentang masalah kehamilan dan persalinan. Dengan banyaknya ibu post sectio caesarea yang berada pada paritas multipara ini mereka sudah sering terpapar informasi yang membuat pengetahuan mereka baik, yang didukung juga dengan pengalaman hamil dan melahirkan sebelumnya yang dapat mempegaruhi pelaksanaan mobilisasi dini pada ibu post sectio caesarea menjadi lebih baik.Berdasarkan karakteristik riwayat SC, pelaksanaan mobilisasi dini dengan kategori baik secara frekuensi lebih banyak terjadi pada responden dengan riwayat SC. Penelitian ini sejalan dengan 
penelitian Winarsih (2013) yang menyatakan bahwa pelaksanaan mobilisasi dini pada ibu yang pernah dilakukan SC, lebih baik dibandingkan dengan ibu yang belum pernah dilakukan SC. Pengetahuan ibu yang didapatkan melalui pengalaman berperan penting mobilisasi dini dilakukan dengan baik (Buhari, Hutagaol, dan Kundre, 2015).

\section{SIMPULAN}

Berdasarkan hasil penelitian mengenai gambaran pelaksanaan mobilisasi dini pada ibu post sectio caesarea di RSUD Soreang tahun 2018, dapat disimpulkan bahwaterdapat 9 (29\%) ibu yang usianya beresiko yaitu kisaran kurang dari 20 tahun dan lebih dari 35 tahun. Sebagian besar responden sebanyak 22 (71\%) tidak beresiko. Mayoritas responden berpendidikan SLTA dengan jumlah 12 orang $(38,7 \%)$. Mayoritas responden tidak bekerja atau sebagai Ibu Rumah Tangga dengan jumlah sebanyak 25 orang (80,6\%).Responden dengan multipara lebih dari setengah, berjumlah sebanyak 19 orang (61\%).Mayoritas responden melakukan sectio caesarea karena riwayat SC atau pernah dilakukan sectio caesarea sebelumnya sebanyak 10 orang $(32,2 \%)$ dan Cephalo Pelvic Disproportion (CPD) sebanyak 8 orang $(25,8 \%)$.Skala nyeri yang paling banyak dialami oleh responden adalah skala nyeri sedang dengan total sebanyak 17 orang (54,8\%).Dari 31 responden yang dilakukan sectiocaesarea, mayoritas responden sebanyak 21 orang $(67,7 \%)$ belum pernah dilakukan sectiocaesarea. Keseluruhan responden mempunyai tanda-tanda vital yang normal dengan total sebesar 100\%.Berdasarkan hasil penelitian ini, didapatkan bahwa sebagian kecil responden yang melaksanakan mobilisasi dini sehingga mendapatkan kategori baik berjumlah 3 orang $(9,7 \%)$. Sedangkan sebagian besar responden tidak melaksanakan mobilisasi dini dengan baik sehingga dikategorikan tidak baik dengan jumlah 28 orang (90,3\%). Berdasarkan karakteristik usia, didapakkan bahwa usia tidak beresiko lebih banyak melakukan mobilisasi dini dibandingkan dengan usia beresiko. Sedangkan berdasarkan karakteristik pendidikan, hasilnya menunjukkan bahwa baik atau tidaknya pelaksanaan mobilisasi dini tidak terkait dengan tingkat pendidikan ibu post sectio caesarea. Berdasarkan karakteristik pekerjaan, diketahui bahwa persentase ibu yang bekerja lebih besar melakukan mobilisasi dini dibandingkan dengan ibu yang tidak bekerja. Selain itu berdasarkan tingkat nyeri, lebih banyak ibu dengan nyeri sedang yang melakukan mobilisasi dini dibandingkan ibu dengan nyeri ringan 
dan berat. Dari kategori paritas, pada multipara lebih banyak melaksanakan mobilisasi dini dengan baik dibandingkan primipara. Berdasarkan karakteristik riwayat SC, pelaksanaan mobilisasi dini dengan kategori baik lebih banyak terjadi pada responden dengan riwayat $\mathrm{SC}$, dibandingkan dengan responden yang tidak pernah dilakukan SC.

\section{DAFTAR RUJUKAN}

Ambarwati. 2008. Asuhan Kebidanan Nifas. Yogyakarta: Mitra Cendikia.

Badan Pusat Statistik. 2012. Survei Demografi dan Kesehatan Indonesia 2012. Jakarta: Badan Pusat Statistik.

Barid, Mubin. 2011. Pengaruh Mobilisasi Dini terhadap Proses Penyembuhan Luka dan Lama Hari Rawat pada Pasien Post Pembedahan Sectio caesarea di Ruang Brawijaya RSUD Kanjuruhan Malang. Malang: PSIK FK Universitas Brawijaya.

Buhari, Hutagaol, dan Kundre. 2015. Hubungan Tingkat Pengetahuan dengan Mobilisasi Dini pada Ibu Nifas di Puskesmas Likupang Timur Kecamatan Likupang Timur. Jurnal Keperawatan. Diakses dari https://ejournal.unsrat.ac.id/index.ph p/jkp/article/view/6688/6208 (diakses pada 1 Januari 2018).

Carpenito, Lynda Juall. 2000. Buku Saku Diagnosa Keperawatan Edisi 6. Jakarta: EGC.

Hartati, Suryani, dan Yati Afiyanti. 2014. Faktor-Faktor Yang Mempengaruhi IbuPostpartum Pasca Seksio Sesarea
Untuk Melakukan Mobilisasi Dini Di RSCM.Jurnal Keperawatan 5.2: 192197.

Hartatik. 2013. Hubungan Pekerjaan Ibu Terhadap Kejadian Sectio Caesarea di RSUD Panembahan Senopati Bantul. AKBID Yogyakarta.

Jokhan , J., \& Hofmeyr, G. J. 2009 . Extra abdominal versus intra abdominal repairof the uterine incision at caesarean section. The Cochrane colaboation and published in the Cochrane library.

Kasdu, Dini. 2003. Operasi Caesar Masalah dan Solusinya. Jakarta: Puspa Swara.

Kementerian Kesehatan RI. 2016. Profil Kesehatan Indonesia. Jakarta: KementerianKesehatan RI.

Potter dan Perry. 2010. Fundamental Keperawatan. Jakarta: Salemba Medika.

Risna. 2013. Hubungan umur dan pekerjaan ibu hamil dengan rencana proses persalinan caesarea di RSUD Hasan Sadikin Bandung Jawa Barat Tahun 2013. Jurnal Kesehatan. Universitas Padjajaran Bandung.

Solehati, Tetti dan Kosasih Cecep Eli. 2015. Relaksasi Dalam KeperawatanMaternitas. Bandung: PT Refika Aditama.

Suciati, Yeni. 2015. Gambaran Karakteristik Ibu Bersalin Sectio Caesarea di RSUD Panembahan Senopati Bantul.

Wijaya, Tony. 2010. Analisis Data Penelitian Menggunakan SPSS. Yogyakarta: Univ. Atma Jaya Yogyakarta. 
163 Jurnal Ilmu dan Teknologi Kesehatan, Vol 5 Nomor 2, Maret 2018, hlm : 149 - 163

Winarsih, Kanti. 2013. Pelaksanaan Mobilisasi Dini pada Klien Paska

Seksio Sesarea. Jurnal Keperawatan 1.1: 77-88. 